\title{
molecules
}

ISSN 1420-3049

http://www.mdpi.org

Full Paper

\section{Synthesis and Antidepressant Evaluation of Three para-Benzoquinone Mono-oximes and Their Oxy Derivatives}

\section{Damião Pergentino de Sousa*, Renata Rabelo Schefer, Ursula Brocksom and Timothy John Brocksom*}

Laboratório de Química Bio-Orgânica, Departamento de Química, Universidade Federal de São Carlos, Caixa Postal 676, 13565-905 São Carlos, SP, Brazil

*Authors to whom correspondence should be addressed. E-mail: brocksom@terra.com.br or damiao50@yahoo.com.br

Received: 18 January 2006 / Accepted: 7 March 2006 / Published: 10 March 2006

\begin{abstract}
A series of three para-benzoquinone mono-oximes and four oxy-derivatives were prepared and tested for their antidepressant properties. The (4E) oxime of 2-isopropyl-5methyl-para-benzoquinone (4) and the corresponding 2-diethylamino-ethyl derivative (10) present antidepressant activities and were slightly more potent than the reference standard.
\end{abstract}

Keywords: Oximes, para-benzoquinones, antidepressant activity.

\section{Introduction}

Depression is a syndrome or collection of symptoms which occur together with sufficient frequency to constitute a recognizable clinical condition. The most common symptoms are apathy, fatigue, depressed mood, depressive thought content and diminished concentration. Theoretical approaches to depression tend to be either strongly biological or strongly psychological in nature. It is now clear that a variety of different factors are implicated in the etiology of depression. There is no doubt that new antidepressants are needed. Existing drugs have undesirable side-effects which reduce compliance with therapy and significant numbers of depressives do not make a satisfactory response [1].

In recent years much work has been published on oxime derivatives with different pharmacological properties: for example: anti-tumor [2], anti-microbial, anticonvulsant [3,4], antiarrhythmic, analgesic and anesthetic properties [5,6]. Many oximes also have been studied to investigate their antidepressant activity [7-9]. Since some oxime derivatives have therapeutic potential as antidepressant drugs, the main aim of the present work was to synthesize several structurally-related 
oximes and to submit them to a preliminary screening to determine the relationship between the structures and their antidepressant activity.

\section{Results and Discussion}

The mono-oximes 4-6 were synthesized in 80, 90 and $82 \%$ yields, respectively, (Scheme 1) by oximation of the corresponding para-benzoquinones 1-3 under standard conditions [10,11].

Scheme 1.<smiles>[R]C1=CC(=O)C(C)=CC1=O</smiles>

$$
\begin{aligned}
& 1 \mathrm{R}=5-i-\mathrm{Pr} \\
& 2 \mathrm{R}=5-\mathrm{Me} \\
& 3 \mathrm{R}=6-\mathrm{Me}
\end{aligned}
$$
reflux, $1.5 \mathrm{~h}$.<smiles>CC1=CC(=O)C(C(C)C)=CC1=NO</smiles>

$4(80 \%)$<smiles>CC1=CC(=NO)C(C)=CC1=O</smiles>

5 (90\%)<smiles>CC1=CC(=NO)C=C(C)C1=O</smiles>

6 (82\%)

Scheme 2.

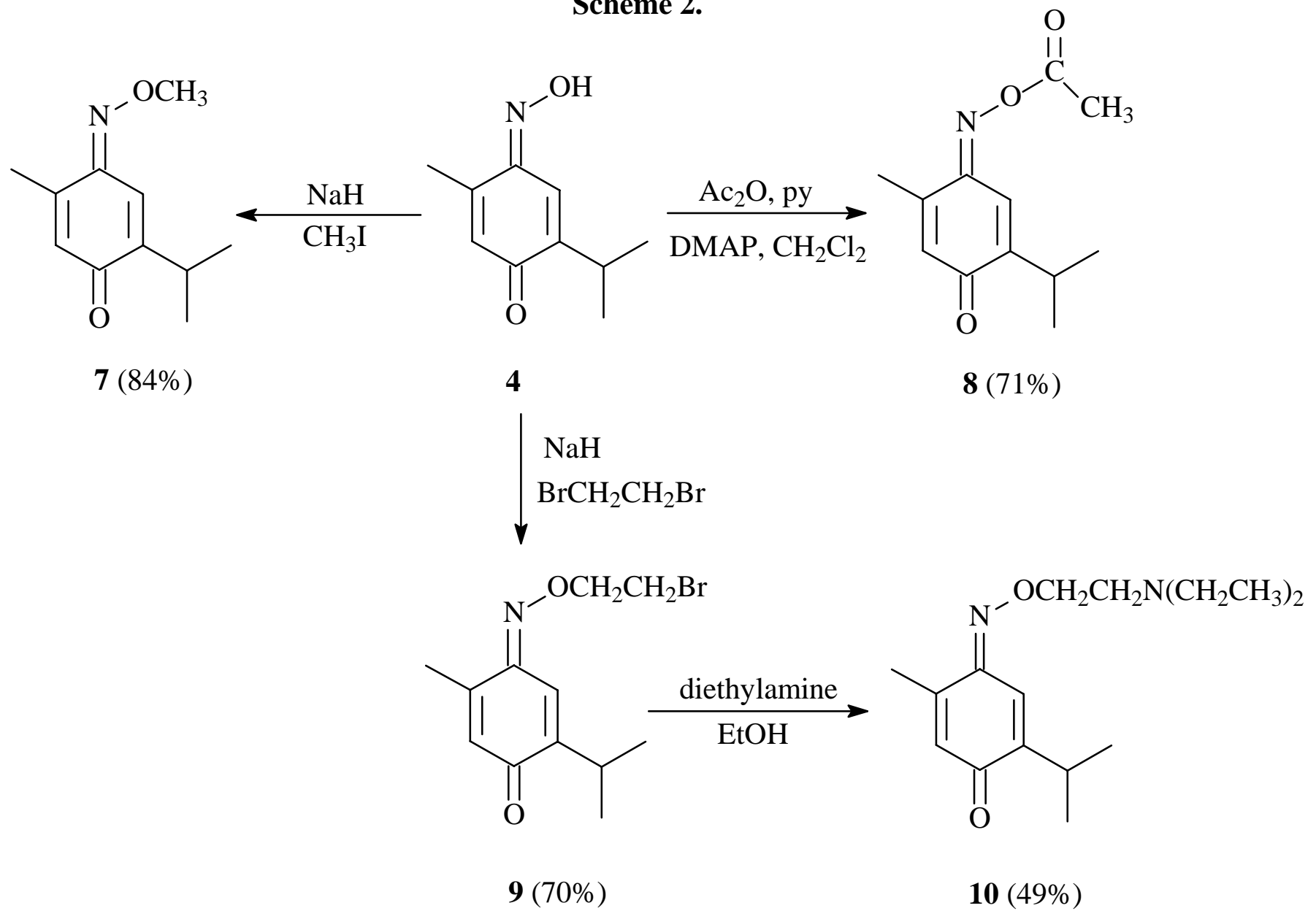


The mono-oxime derivatives 7-9 (Scheme 2) were obtained by standard alkylation and acylation reactions of compound 4 . The ether 7 was synthesized in $84 \%$ yield with methyl iodide whereas reaction of $\mathbf{4}$ with acetic anhydride resulted in $\mathbf{8}$ in 71\% yield. Treatment of $\mathbf{4}$ with dibromoethane gave the bromide 9 in $70 \%$ yield, which was further converted with diethylamine into the amine $\mathbf{1 0}$ in $49 \%$ yield.

\section{Antidepressant activity}

None of the compounds tested caused mortality up to a dose of $100 \mathrm{mg} / \mathrm{kg}$ i.p. in mice. The antidepressant evaluation of the compounds is presented in Table 1.

Table 1. Antidepressant activity of compounds 4-10.

\begin{tabular}{|c|c|c|}
\hline Compound & $\begin{array}{c}\text { Dose } \\
\text { (mg/kg i.p.) }\end{array}$ & $\begin{array}{c}\text { Duration of immobility } \\
\text { (sec } \pm \text { S.E.M.) }\end{array}$ \\
\hline Control & --- & $205.5 \pm 4.4$ \\
Imipramine & 15 & $178.3 \pm 7.8^{*}$ \\
$\mathbf{4}$ & 10 & $174.8 \pm 8.9^{*}$ \\
$\mathbf{5}$ & 10 & $188.8 \pm 12.7$ \\
$\mathbf{6}$ & 10 & $183.8 \pm 14.6$ \\
$\mathbf{7}$ & 10 & $207.1 \pm 6.0$ \\
$\mathbf{8}$ & 10 & $212.5 \pm 4.3$ \\
$\mathbf{9}$ & 10 & $189.5 \pm 5.8$ \\
$\mathbf{1 0}$ & 10 & $175.1 \pm 7.8^{*}$ \\
\hline
\end{tabular}

$* p<0.05$

The forced swimming test showed a relationship between structure and antidepressant activity. Compounds $\mathbf{4}$ and $\mathbf{1 0}$ were shown to be nearly equipotent and slightly more potent than imipramine, the drug used as reference standard.

Of the three mono-oximes studied only $\mathbf{4}$ was active, indicating the relevance of the isopropyl group for the antidepressant activity in this series. The oxime ethers $\mathbf{7}$ and $\mathbf{9}$, as well as the acetyl monooxime 8, present no statistical difference from the control group in reducing the immobility time of mice. The amine derivative $\mathbf{1 0}$ significantly shortened this immobility period, which is perhaps not surprising considering that its structure is similar to the second-generation antidepressant drug fluvoxamine [8].

The behavioural despair test is a classic model very well known for screening of new antidepressant drugs. The onset of immobility is delayed by pretreatment with a wide variety of antidepressants. Effective agents include tricyclics, MAOIs, most atypical antidepressants, deprivation of rapid eye movement sleep and electroconvulsive shock [1]. Indeed, there is a significant correlation between the potency of antidepressants in the behavioural despair test and their clinical potency, which has not been demonstrated with any other animal model of depression [12].

The preliminary screening results reported in this paper show that compounds $\mathbf{4}$ and $\mathbf{1 0}$ are psychoactive, evidencing a pharmacological profile of an antidepressant drug. Our results also 
suggested that by appropriate structural modification of para-benzoquinone mono-oximes, it may be possible to develop novel therapeutic agents against depression.

\section{Acknowledgements}

We thank FAPESP, CNPq and CAPES for financial support and Cristalia Produtos Químicos Farmacêuticos Ltda for a donation of imipramine.

\section{Experimental Section}

\section{Chemistry}

GLC analyses were conducted on a Shimadzu GC-17A instrument equipped with a flame-ionization detector, using a DB-1 (30 m x $0.25 \mathrm{~mm}$ ) glass column. Column chromatography was performed on silica gel 60 (70-230 mesh ASTM Merck). Radial thin-layer chromatography was carried out on a Chromatotron model 8924 (silica gel 60PF274 Merck). Melting points were determined on a Microquímica MQWAPF-301 apparatus and are uncorrected. Infrared spectra were recorded with a Bomen Hartman \& Braun MB-Series spectrometer. ${ }^{1} \mathrm{H}$ - and ${ }^{13} \mathrm{C}$ - NMR spectra were recorded at 200 or $50 \mathrm{MHz}$, respectively, either on a Bruker ARX-200 or a Bruker DRX-400 spectrometer in $\mathrm{CDCl}_{3}$ with TMS as internal standard. The mass spectra were recorded on a Micromass mass spectrometer Quattro LC, coupled with a chemical ionization source (reagent $\mathrm{MeOH}$ ) under atmospheric pressure (APCI). Microanalyses were performed on a Fisons EA 1108 CHNS-O analyzer, at the Chemistry Department, Universidade Federal de São Carlos. Solvents were purified prior to use: dichloromethane and hexane were refluxed over $\mathrm{P}_{2} \mathrm{O}_{5}$, distilled and stored over molecular sieves; pyridine was stirred and refluxed over $\mathrm{KOH}$, distilled and stored over $\mathrm{KOH}$; acetic anhydride was stirred over $\mathrm{P}_{2} \mathrm{O}_{5}$ and $\mathrm{K}_{2} \mathrm{CO}_{3}$, distilled and stored over molecular sieves.

General procedure for the syntheses of the oximes 4, 5 and $\mathbf{6 :}$

A solution of the hydroxylamine hydrochloride $(0.221 \mathrm{~g}, 3.18 \mathrm{mmol})$ and sodium acetate $(0.169 \mathrm{~g}$, $2.08 \mathrm{mmol})$ were added to para-benzoquinone $(1.22 \mathrm{mmol})$ in $\mathrm{EtOH}(11.70 \mathrm{ml})$, and the resulting mixture was stirred and refluxed for 1.5 hours. After the solvent was evaporated under reduced pressure, the solid residue was diluted in water $(50 \mathrm{~mL})$ and extracted with a mixture of ethyl acetate and ethyl ether $(1: 1,3 \times 20 \mathrm{~mL})$. The organic layer was washed with aqueous $\mathrm{NaHCO}_{3}(3 \times 20 \mathrm{~mL})$ and $\mathrm{NaCl}(3 \times 20 \mathrm{~mL})$, dried over anhydrous $\mathrm{Na}_{2} \mathrm{SO}_{4}$ and the solvent was evaporated under reduced pressure. The solid residue was washed with hexane $(4 \times 20 \mathrm{~mL})$ to eliminate soluble impurities.

\section{(4E)-2-isopropyl-5-methylbenzo-1,4-quinone 4-oxime (4)}

Yield: 80\%; Mp 142.6-143.2 ${ }^{\circ} \mathrm{C}$; lit. $140{ }^{\circ} \mathrm{C}$ [13], IR ( $\left.v_{\max }, \mathrm{KBr}, \mathrm{cm}^{-1}\right)$ : 3180, 2964, 1639, 1605, 1439, 1241, 1056; ${ }^{1} \mathrm{H}-\mathrm{NMR} \delta: 1.13$ (6H, d, $J=6.8 \mathrm{~Hz}$ ), 2.20 (3H, d, $J=1.3 \mathrm{~Hz}$ ), 3.07 (1H, d hept, $J=1.1$ and $6.8 \mathrm{~Hz}), 6.27(1 \mathrm{H}, \mathrm{q}, J=1.3 \mathrm{~Hz}), 7.56(1 \mathrm{H}, \mathrm{d}, J=1.1 \mathrm{~Hz}) ;{ }^{13} \mathrm{C}-\mathrm{NMR} \delta: 16.8,21.5,26.3,118.2,128.4$, 
146.0, 147.9, 150.1, 186.8; MS m/z (\%): $180[\mathrm{M}+1]^{+}$(100), 163 (4), 109 (28); Anal. Calcd. for $\mathrm{C}_{10} \mathrm{H}_{13} \mathrm{NO}_{2}$ : $7.82(\mathrm{~N}), 67.02(\mathrm{C}), 7.31(\mathrm{H})$; Found: $7.56(\mathrm{~N}), 67.11(\mathrm{C}), 7.55(\mathrm{H})$.

(1E)-2,5-dimethylbenzo-1,4-quinone oxime (5)

Yield: 90\%; Mp 126.5-127.4 ${ }^{\circ} \mathrm{C}$; IR ( $\left.v_{\text {max }}, \mathrm{KBr}_{\mathrm{cm}}{ }^{-1}\right)$ : 3232, 2889, 1642, 1611, 1353, 1187, 1025; ${ }^{1} \mathrm{H}-\mathrm{NMR} \delta$ : 2.03 (3H, d, $J=1.4$ Hz), 2.19 (3H, d, $J=1.3 \mathrm{~Hz}$ ), 6.31 (1H, q, $J=1.3 \mathrm{~Hz}$ ), 7.63 (1H, q, $J=1.4$ $\mathrm{Hz}) ;{ }^{13} \mathrm{C}-\mathrm{NMR} \delta: 15.8,16.8,121.5,128.2,138.9,146.9,150.2,187.9 ; \quad \mathrm{MS}\left(\mathrm{m} / \mathrm{z}(\%): 152[\mathrm{M}+1]^{+}\right.$ (100), 124 (5), 109 (7); Anal. Calcd. for $\mathrm{C}_{8} \mathrm{H}_{9} \mathrm{NO}_{2}$ : 9.27 (N), 63.56 (C), $6.00(\mathrm{H})$. Found: $9.13(\mathrm{~N})$, $63.13(\mathrm{C}), 5.88(\mathrm{H})$.

(4E)-2,6-dimethylbenzo-1,4-quinone oxime (6)

Yield: 82\%; Mp 138.4-139.0 ${ }^{\circ} \mathrm{C}$; IR ( $v_{\text {max. }}, \mathrm{KBr}, \mathrm{cm}^{-1}$ ): 3216, 2853, 1632, 1604, 1423, 1199, 1058; ${ }^{1} \mathrm{H}-\mathrm{NMR} \delta: 2.01$ (3H, d, J=1.1 Hz), 2.04 (3H, d, $J=1.2 \mathrm{~Hz}$ ), 7.02 (1H, q, $\left.J=1.1 \mathrm{~Hz}\right), 7.58$ (1H, q, $J=1.2$ $\mathrm{Hz}) ;{ }^{13} \mathrm{C}-\mathrm{NMR} \delta: 15.7,16.3,120.5,133.8,136.4,139.0,149.2,187.8 ; \mathrm{MS} \mathrm{m} / \mathrm{z}(\%): 152[\mathrm{M}+1]^{+}(100)$, 138 (5), 122 (14); Anal. Calcd. for $\mathrm{C}_{8} \mathrm{H}_{9} \mathrm{NO}_{2}$ : $9.27(\mathrm{~N}), 63.56(\mathrm{C}), 6.00(\mathrm{H})$. Found: $9.28(\mathrm{~N}), 63.23(\mathrm{C})$, $5.98(\mathrm{H})$.

(4E)-2-isopropyl-5-methylbenzo-1,4-quinone 4-(O-methyloxime) (7)

A solution of $4(0.100 \mathrm{~g} ; 0.56 \mathrm{mmol})$ in dichloromethane $(2.5 \mathrm{~mL})$ and THF $(0.1 \mathrm{~mL})$, was added to sodium hydride (60\%, $0.020 \mathrm{~g}, 0.83 \mathrm{mmol}$, previously washed several times with dry hexane) and the resulting mixture was stirred for 1 hour at room temperature. Methyl iodide $(0.16 \mathrm{~mL}, 2.57 \mathrm{mmol})$ was added and the reaction was allowed to stand at room temperature for 18 hours. The mixture was diluted with water $(20 \mathrm{~mL})$ and the layers were separated. The aqueous layer was extracted with ethyl acetate $(3 \times 20 \mathrm{~mL})$. The combined organic layers were washed with aqueous $\mathrm{NH}_{4} \mathrm{Cl}(3 \times 20 \mathrm{~mL})$, dried over anhydrous $\mathrm{Na}_{2} \mathrm{SO}_{4}$ and the solvents were evaporated under reduced pressure. The oily residue was purified by radial thin-layer chromatography (9:1 hexane-ethyl acetate as eluent) to provide a pure sample of 7 : $(0.091 \mathrm{~g}, 0.470 \mathrm{mmol}, 84 \%$ yield $)$. IR $\left(v_{\text {max }}, \mathrm{KBr}_{\mathrm{cm}}{ }^{-1}\right)$ : 2972, 1637 , 1613, 1518, 1372, 1240; ${ }^{1} \mathrm{H}-\mathrm{NMR} \delta: 1.12$ (6H, d, $\left.J=6.8 \mathrm{~Hz}\right), 2.16$ (3H, d, $\left.J=0.8 \mathrm{~Hz}\right), 3.06$ (1H, d hept, $J=6.8,0.8 \mathrm{~Hz}), 3.46(3 \mathrm{H}, \mathrm{s}), 6.26(1 \mathrm{H}, \mathrm{d}, J=0.8 \mathrm{~Hz}), 7.38(1 \mathrm{H}, \mathrm{d}, J=0.8 \mathrm{~Hz}) ;{ }^{13} \mathrm{C}-\mathrm{NMR} \delta: 16.8,22.1$, 26.6, 63.7, 118.4, 129.1, 145.6, 149.0, 149.6, 186.7; MS m/z (\%): 194 [M+1] $]^{+}$(100), 179 (26), 164 (30), 152 (5); Anal. Calcd. for $\mathrm{C}_{11} \mathrm{H}_{15} \mathrm{NO}_{2}$ : $7.25(\mathrm{~N}), 68.37$ (C), $7.82(\mathrm{H})$. Found: $6.98(\mathrm{~N}), 67.99(\mathrm{C})$, $7.72(\mathrm{H})$.

(4E)-2-isopropyl-5-methylbenzo-1,4-quinone 4-(O-acetyloxime) (8)

Pyridine (0.34 $\mathrm{mL}$ ) was added to a mixture of 4 (0.100 g, $0.56 \mathrm{mmol})$, DMAP (catalytic amount) and acetic anhydride $(0.13 \mathrm{~mL}, 1.36 \mathrm{mmol})$. The resulting mixture was stirred for 20 hours at room temperature. The mixture was diluted with ethyl ether $(20 \mathrm{~mL})$ and washed successively with $10 \%$ aqueous $\mathrm{CuSO}_{4}(3 \times 20 \mathrm{~mL}), 5 \%$ aqueous $\mathrm{NaHCO}_{3}(2 \times 20 \mathrm{~mL})$ and distilled water $(20 \mathrm{~mL})$, dried 
over $\mathrm{Na}_{2} \mathrm{SO}_{4}$ and the solvent was evaporated under reduced pressure. The solid residue was purified by radial thin-layer chromatography (9:1 hexane-ethyl acetate as eluent) to provide a pure sample of $\mathbf{8}$ : (0.088 g, 0.40 mmol, 71\% yield). Mp $68.4-70.4{ }^{\circ} \mathrm{C}$; IR ( $v_{\text {max }}, \mathrm{KBr}, \mathrm{cm}^{-1}$ ): 2965, 1785, 1650, 1630, 1601, 1522, 1249, 1150; ${ }^{1} \mathrm{H}-\mathrm{NMR} \delta: 1.13$ (6H, d, $J=6.9 \mathrm{~Hz}$ ), 2.26 (3H, d, $J=1.4 \mathrm{~Hz}$ ), 2,37 (3H, s), 3.09 (1H, d hept, $J^{1}=1.1 \mathrm{~Hz}$ and $\left.J^{2}=6.9 \mathrm{~Hz}\right), 6.39(1 \mathrm{H}, \mathrm{d}, J=1.4 \mathrm{~Hz}), 7.39(1 \mathrm{H}, \mathrm{d}, J=1.1 \mathrm{~Hz}) ;{ }^{13} \mathrm{C}-\mathrm{NMR} \delta$ : 17.3, 19.8, 21.7, 34.1, 118.4, 131.1, 145.5, 151.9, 154.1, 168.9, 186.7; MS m/z (\%): $222[\mathrm{M}+1]^{+}$(45), 180 (100), 164 (24), 152 (18), 138 (30), 110 (90); Anal. Calcd. for $\mathrm{C}_{12} \mathrm{H}_{15} \mathrm{NO}_{3}$ : 6.33 (N), 65.14 (C), $6.79(\mathrm{H})$. Found: $6.00(\mathrm{~N}), 64.89(\mathrm{C}), 6.56(\mathrm{H})$.

\section{(4E)-2-isopropyl-5-methylbenzo-1,4-quinone 4-[O-(2-bromoethyl)-oxime] (9)}

A solution of $4(0.118 \mathrm{~g}, 0.66 \mathrm{mmol})$ in dichloromethane $(2.5 \mathrm{~mL})$ and THF $(0.1 \mathrm{~mL})$ was added to sodium hydride (60\%, $0.020 \mathrm{~g}, 0.83 \mathrm{mmol}$, previously washed several times with dry hexane) and the resulting mixture was stirred for 1 hour at room temperature. Dibromoethane $(0.11 \mathrm{~mL}, 1.32 \mathrm{mmol})$ was added and the reaction was allowed to stand at room temperature for 6 hours. The mixture was diluted with water $(20 \mathrm{~mL})$ and the layers were separated. The aqueous layer was extracted with ethyl acetate $(3 \times 20 \mathrm{~mL})$. The organic layers were combined, washed with aqueous $\mathrm{NH}_{4} \mathrm{Cl}(3 \times 20 \mathrm{~mL})$, dried over anhydrous $\mathrm{Na}_{2} \mathrm{SO}_{4}$ and the solvent was evaporated under reduced pressure. The oily residue was purified by radial thin-layer chromatography (9:1 hexane-ethyl acetate as eluent) to provide a pure sample of 9: (0.132 g, $0.46 \mathrm{mmol}, 70 \%$ yield). IR ( $\left.v_{\text {max }}, \mathrm{KBr}, \mathrm{cm}^{-1}\right): 2963,1630,1623,1424,1239$, 1077, 1010; ${ }^{1} \mathrm{H}-\mathrm{NMR} \delta: 1.11$ (6H, d, J=6.7 Hz), 2.14 (3H, s), 3.05 (1H, m), 3.62 (2H, t, J=6.3 Hz), $4.59(2 \mathrm{H}, \mathrm{t}, J=6.3 \mathrm{~Hz}), 7.39$ and $6.28(2 \mathrm{H}, \mathrm{s}) ;{ }^{13} \mathrm{C}-\mathrm{NMR} \delta: 16.8,21.6,26.7,28.9,75.0,118.5,129.5$, 133.3, 145.4, 149.6, 186.7; MS m/z (\%): 287 [M+1] (100), 268 (10), 235 (15), 179 (45), 163 (18); Anal. Calcd. for $\mathrm{C}_{12} \mathrm{H}_{16} \mathrm{NO}_{2} \mathrm{Br}: 4.89(\mathrm{~N}), 50.37(\mathrm{C}), 5.64(\mathrm{H})$. Found: $4.76(\mathrm{~N}), 50.24(\mathrm{C}), 5.54(\mathrm{H})$.

(4E)-2-isopropyl-5-methylbenzo-1,4-quinone-(O-[2-(diethylamino)-ethyl]-oxime) (10)

A solution of (9) $(0.40 \mathrm{~g} ; 1.39 \mathrm{mmol})$ in $\mathrm{EtOH}$ (15 ml) was added to diethylamine (0.43 ml, $0.307 \mathrm{~g}$; $4.2 \mathrm{mmol}$ ) and the resulting mixture was stirred for 6 hours at room temperature. The solvent and excess diethylamine were evaporated under reduced pressure. The oily residue was purified by radial thin-layer chromatography (9:1 hexane-ethyl acetate as eluent) to provide a pure sample of 10: (0.192 g, 0.69 mmol, 49\% yield). IR ( $\left.v_{\text {max }}, \mathrm{KBr}, \mathrm{cm}^{-1}\right)$ : 2966, 1640, 1626, 1466, 1306, 1240, 1044; ${ }^{1} \mathrm{H}-$ NMR $\delta: 1.10$ (6H, t, $J=7.2 \mathrm{~Hz}), 1.15(6 \mathrm{H}, \mathrm{d}, J=6.9 \mathrm{~Hz}), 2.15$ (3H, d, $J=1.3 \mathrm{~Hz}), 2.7$ (4H, q, $J=7.2 \mathrm{~Hz}$ ), $2.95(2 \mathrm{H}, \mathrm{t}, J=5.9 \mathrm{~Hz}), 3.08\left(1 \mathrm{H}, \mathrm{d}\right.$ hept, $\left.J^{1}=1.1, J^{2}=6.9 \mathrm{~Hz}\right), 4.5(2 \mathrm{H}, \mathrm{t}, J=5.9 \mathrm{~Hz}), 6.28(1 \mathrm{H}, \mathrm{q}, J=1.3$ Hz), 7.39 (1H, d, $J=1.1 \mathrm{~Hz}) ;{ }^{13} \mathrm{C}-\mathrm{NMR} \delta: 11.2,16.8,21.7,26.7,47.5,50.8,74.2,118.6,129.2,145.5$, 149.3, 149.9, 186.7; MS m/z (\%): 279 [M+1] ${ }^{+}$(100), 164 (13), 116 (11); Anal. Calcd. for $\mathrm{C}_{16} \mathrm{H}_{24} \mathrm{~N}_{2} \mathrm{O}_{2}$ : $10.06(\mathrm{~N}), 69.03(\mathrm{C}), 9.41(\mathrm{H})$. Found: $9.80(\mathrm{~N}), 68.65(\mathrm{C}), 9.12(\mathrm{H})$.

\section{Acute toxicity}

The toxicity study was performed with different doses of compounds to groups of mice $(n=10)$ administered intraperitoneally (i.p.), and mortality was recorded for 48 h [14]. 


\section{Pharmacology}

The forced swimming (behavioural despair) test was employed on 6-8 week old male Swiss albino mice (weighing 28-36 g). The animals were maintained at constant room temperature $\left(23 \pm 1^{\circ} \mathrm{C}\right)$ and on a 12/12 hour light-dark cycle (light from 07:00 to 19:00 hours) with free access to food and water. They were acclimatized for a minimum of 7 days.

The synthesized compounds (10 mg/kg) and imipramine (15 mg/kg) were dissolved in 5\% Tween 80 and saline $(0.9 \%)$, respectively. They were injected i.p. into mice $(n=6)$ in dose/volume of 1 $\mathrm{mL} / 100 \mathrm{~g}$, one hour prior to testing. Saline was used as control. One hour after injection the mice were placed one at a time into a plexi-glass cylinder (22 cm height, $10 \mathrm{~cm}$ diameter) containing $8 \mathrm{~cm}$ height of water at $24{ }^{\circ} \mathrm{C}$ and the immobility time of each mouse was measured between 2 and 6 min [15].

\section{Statistical analysis}

Analysis of variance and Student's "t" test were made and the results were considered significant when $p<0.05$.

\section{References}

1. Willner, P. Behavioural models in psychopharmacology: theoretical, industrial, and clinical perspectives; Cambridge University Press: Cambridge, U.K., 1991; pp. 94-105.

2. Soga, S.; Sharma, S.V.; Shiotsu, Y.; Shimizu, M.; Tahara, H.; Yamaguchi, K.; Ikuina, Y.; Murakata, C., Tamaoki, T., Kurebayashi, J., Schulte, T.W., Neckers, L.M., Akinaga, S. Cancer Chemoth. Pharm. 2001, 48, 435-445.

3. Karakurt, A.; Dalkara, S.; Ozalp, M.; Ozbey, S.; Kendi, E.; Stables, J.P. Eur. J. Med. Chem. 2001, 36, 421-433.

4. Brightman, T.; Ye, J. H.; Ortiz-Jimenez, E.; Flynn, E.J.; Wu, W.H.; McArdle, J.J. Brain Res. 1995, 678, 110-116.

5. Aboul-Enein, M.N.; El-Azzouny, A.; Abdallah, N.A.; Maklad, Y.A.; Saleh, O.A.; Ebeid, M. Y. Il Farmaco 1998, 53, 197-208.

6. Schenone, S.; Bruno, O.; Ranise, A.; Bondavalli, F; Filippelli, W.; Falcone, G.; Rinaldi, B. Il Farmaco, 2000, 55, 495-498.

7. Davrinche, C.; Nguyentrixuong, E.; Elhamad, Y.; Reynaud, P.; Rinjard, P.;Tran, G. Eur. J. Med. Chem. 1992, 27, 765-778.

8. Bozdag, O.; Gumusel, B.; Demirdamar, R.; Buyukbingol, E.; Rolland, Y.; Ertan, R. Eur. J. Med. Chem. 1998, 33, 133-141.

9. Ertan, R.; Bozdag, O.; Kesici, B.; Palaska, E.; Ertan, M. Acta Pharm. Turc. 1998, 40, 131-135.

10. Suginome, H.; Ohki, T., Nagaoka, A.; Senboku, H. J. Chem. Soc. Perkin Trans.1, 1992, 18491854.

11. Sharghi, H.; Sarvari, M. H. Synlett. 2001, 1, 99-101.

12. Willner, P. Psychopharmacology 1984, 83, 1-16.

13. Goldschmidt, H.; Schmidt, H. Ber. Dtsch. Chem. Ges. 1884, 17, 2060-2065. 
14. Litchfield J.J.; Wilcoxon F.J. J. Pharmacol. Exp. Ther. 1949, 96, 99-113.

15. Porsolt, R.D.; Le Pichon, M.; Jalfre, M. Nature 1977, 266, 730-732.

Sample availability: Available from the authors.

(C) 2006 by MDPI (http://www.mdpi.org). Reproduction is permitted for noncommercial purposes. 